\title{
Approaches to the Treatment of Zero Equivalence in a Bilingual Dictionary
}

Marjeta Vrbinc, Department of English, Faculty of Arts, University of Ljubljana, Ljubljana, Slovenia (marjeta.vrbinc@ff.uni-lj.si)

and

Alenka Vrbinc, Faculty of Economics, University of Ljubljana, Ljubljana, Slovenia (alenka.vrbinc@ef.uni-lj.si)

\begin{abstract}
The article discusses the treatment of zero equivalence in an English-Slovene dictionary (ESD). The absence of equivalents in the TL is marked by two symbols: Ø (a complete absence of any equivalent) and \# (equivalence at the level of the entire message rather than at word level). Sixty-five lemmata in the ESD contain a slashed zero, a hash or both, but one and the same entry can contain more than one symbol. Detailed results are presented by parts of speech of the lemmata, starting with a numerical analysis, which is followed by analysis of the content of illustrative examples. Then follows a detailed discussion of lemmata expressing pragmatic meaning in the $\mathrm{SL}$, lemmata with lexico-grammatical, grammatical and lexical differences between the SL and the TL as well as lemmata with a number of SL senses included under one sense in the ESD. In the ESD, the problem of zero equivalence is mostly solved by the inclusion of translated examples of use. Another method employed in the ESD is the use of short descriptions of the function of the lemma or one of its senses. In this way, a more successful and thorough retrieval of information can be achieved with every look-up.
\end{abstract}

Keywords: BILINGUAL DICTIONARY, CONTEXT, COTEXT, DESCRIPTIONS OF FUNCTIONS, EXAMPLES OF USE, GRAMMATICAL DIFFERENCES, LEXICAL DIFFERENCES, LEXICO-GRAMMATICAL DIFFERENCES, PRAGMATIC SENSES, ZERO EQUIVALENCE

Opsomming: Benaderings tot die hantering van zero-ekwivalensie in ' $n$ tweetalige woordeboek. Die hantering van zero-ekwivalensie in 'n Engels-Sloveense woordeboek (ESD) word in hierdie artikel bespreek. Die afwesigheid van ekwivalente in die doeltaal (DT) word aangedui deur twee simbole: $\varnothing$ ('n totale afwesigheid van enige ekwivalent) en \# (ekwivalensie op die vlak van die volle boodskap eerder as op die vlak van 'n woord). Vyf-en-sestig lemmas in die ESD bevat ' $n$ nul met 'n skuinsstreep daardeur, 'n hutsmerker of albei, maar een inskrywing kan meer as een simbool bevat. Die resultate word uitvoerig voorgehou volgens die woordsoort van die lemmas, en begin met 'n syferkundige ontleding, gevolg deur 'n ontleding van die inhoud van die toeligtende voorbeelde. Daarna volg 'n gedetailleerde bespreking van lemmas wat 'n pragmatiese betekenis uitdruk in die BT, lemmas met leksiko-grammatikale, grammatikale en leksikale verskille tussen die BT en die DT, sowel as lemmas met 'n aantal BT-betekenisse gegroepeer onder een betekenisonderskeiding in die ESD. Die probleem van zero-ekwivalensie word meestal in die ESD opgelos deur die insluiting van vertaalde gebruiksvoorbeelde. 'n Ander metode wat in die 
ESD gebruik word, is die gebruik van kort beskrywings van die lemma se funksie of van een van sy betekenisse. Op hierdie manier kan 'n meer suksesvolle en deeglike onttrekking van inligting gedoen word tydens elke opsoeksessie.

Sleutelwoorde: TWEETALIGE WOORDEBOEK, KONTEKS, KOTEKS, BESKRYWINGS VAN FUNKSIES, GEBRUIKSVOORBEELDE, GRAMMATIKALE VERSKILLE, LEKSIKALE VERSKILLE, LEKSIKO-GRAMMATIKALE VERSKILLE, PRAGMATIESE BETEKENISONDERSKEIDINGS, ZERO-EKWIVALENSIE

\section{Introduction}

The most salient element of a lexicographic description, regardless of the type and scope of a dictionary and its intended users, is the semantic component. Bilingual lexicographers are therefore expected to find equivalents in the target language (TL) that correspond semantically to the source language (SL) lexical items not only in one particular context but more universally (Adamska-Sałaciak 2010: 388; Atkins 1992/1993: 44f). Lexicographers, however, often come across cases when they fail to find suitable equivalents. This can happen with any lexical item; this is why the lexicographers must try to find and use means other than lexical equivalence (Zgusta 1971: 323). The provision of dictionary equivalents in the TL often depends on co-text: i.e., the linguistic environment of a word, or context, i.e., the non-verbal environment in which a word is used. There is a strong relationship between language and context, and seeking equivalence of meaning is in fact seeking equivalence for the situational context (Hu 2010: 324). It should be stressed that carefully selected co-text or context provided in a mono- as well as in a bilingual dictionary in the form of illustrative examples plays a very important role, since examples disambiguate and/ or specify the meaning of the lexical item in question (Zgusta 1971: 337), and "any semantic phenomenon, whether in the field of designation, connotation, or the range of application can be clarified by means of examples" (Zgusta ibid.: 340).

When talking about equivalents in two languages, we actually refer to what Adamska-Sałaciak (2010: 389 ) explains as a particular sense of a lexical item $X$ in the SL being equivalent to a particular sense of a lexical item $Y$ in the TL (for more on the problem of equivalence see Adamska-Sałaciak 2010, 2011; Atkins and Rundell 2008: 468; Wiegand 2005). The relation between the SL lexical item and the TL lexical item is regarded as the equivalent relation (Gouws 2002: 195196). Equivalent relations are generally of three types, which are variously referred to as absolute equivalence, partial equivalence and explanatory equivalence by Zgusta (1971: 312-325); full equivalence, partial equivalence and non-equivalence by Wiegand (2002); as full equivalence (congruence), partial equivalence (divergence) and zero equivalence (surrogate equivalence) by Gouws (2002: 196); and multiple equivalence, zero equivalence and partial equivalence by Šipka (2015: 51). Adamska-Sałaciak (2011: 4), however, enumerates four varieties of equivalence: cognitive, translational, explanatory and 
functional. According to Gouws (2002: 196), full equivalence implies that the SL and the TL lexical items are equivalent lexically, pragmatically and semantically, which means that the TL lexical item can replace the SL lexical item in all contexts and uses. From the lexicographic perspective, full equivalence is considered relatively unproblematic, but as Zgusta (1971: 312) points out, absolute equivalents are quite rare. The equivalent relation that is most common in bilingual dictionaries is partial equivalence, where the semantic component of the dictionary entry consists of several TL equivalents that cover the entire spectrum of meaning of the SL item (cf. Zgusta ibid.: 315). These equivalents usually share certain semantic components, i.e., they are considered to be partial synonyms. Partial equivalence is characterized by the fact that the "polysemy structure of a source language lexical item does not correspond with that of the target language on the systemic level" (Wiegand 2002: 243). Gouws (2002: 197-199) further distinguishes between lexical divergence, semantic divergence and polydivergence. The last and the most intriguing semantic relation is that of surrogate or zero equivalence, characterized by a lack of equivalent in the TL. Gouws (2002: 200) points out that "[s]urrogate equivalents belong to different categories and their choice is determined by the nature of the lexical gap". Among solutions which can be adopted in the case of zero equivalence, Svensén (2009: 261, 274-275) enumerates direct borrowing, loan translation, new coinage, encyclopedic explanations, etc., whereas Šipka (2015: 52-53) stresses the importance of explanatory glosses combined with adopting an SL word in lexicography and possibly translation and cultural notes in language teaching. Since zero equivalence in the case of culture-specific words can be solved in a bilingual dictionary in the ways mentioned by Svensén and Šipka, culture-specific words are not the subject of our research.

Apart from zero equivalence in culture-specific lexical items, other cases of zero equivalence can be found. Although this may happen with any lexical unit, Zgusta (1971: 323-325; 1984: 149) enumerates other types of lexical items that often lack equivalents in other languages: onomatopoeia, interjections, functional words, particles and similar lexical units. Here, functional or grammatical words should be especially highlighted, since these often prove to be problematic when trying to establish equivalence. This can be explained by the distinct function performed by grammatical words in a sentence and by the fact that they are used differently in different languages. Among the grammatical words that are problematic from the dictionary-making perspective, Atkins and Rundell (2008: 164-165) enumerate the following: prepositions, conjunctions, pronouns (demonstratives, possessives, quantifiers), auxiliary verbs and the modals, determiners including the definite and indefinite articles, numerals, negatives, and predeterminers. Many of these grammatical words are also identified in our study as being difficult to treat in an English-Slovene dictionary. This can be explained by the fact that no conceptual content can be established in the TL, but as Šipka (2015: 69) points out "the operation that is performed by a lexeme in the SL can be rendered in the TL by some kind of 
grammatical manoeuvre or any other non-lexical means". He therefore stresses that in this case, we can talk about zero equivalence at the juncture of lexical and grammatical elements.

The aim of this study is to investigate how to compensate for absent equivalents in the TL in a decoding English-Slovene dictionary (hereafter referred to as ESD) which is in its final stages of completion. Since the most important function of a bilingual dictionary is to offer equivalents that can be used in translation from the SL into the TL, special attention is paid to different methods employed by the lexicographers compiling a bilingual dictionary to provide acceptable solutions when dictionary equivalent(s) do not exist in the TL as well as to those cases which are solved neither by a descriptive equivalent nor by a loan word. The ESD contains many innovative features that are untypical of existing English-Slovene dictionaries. Among the innovations, two symbols, i.e., $\varnothing$ and \#, should be mentioned, both of them being employed to mark the absence of equivalents in the TL. The importance of explicitly marking zero equivalence in a bilingual dictionary is also stressed by Wiegand (2002: 248-249), who proposes the use of the symbol "0". It should, however, be stressed that cases of true zero equivalence are rare in the ESD, because the lexicographers tried to mark the fewest possible lemmata or their senses with the symbol Ø indicating a complete absence of any equivalent, but instead used the hash sign. The symbol \# implies no equivalence at the word level, but if the untranslatable SL lexical item is used in an example illustrating its use, be it a sentence or a truncated phrase, it can be rendered into the TL, which means that equivalence is reached at the level of the entire message. This clearly indicates the importance of the role played by co-text and context in retrieving semantic information on the SL lexical items.

\section{Methodology}

The ESD investigated in this research contains 53,233 lemmata and 16,274 secondary lemmata (i.e., phraseological units included in the idioms section and multi-word verbs included in the phrasal verbs section) and belongs to the group of more comprehensive bilingual English-Slovene dictionaries; at the same time, it is the only pedagogically- and didactically-oriented bilingual dictionary compiled so far in Slovenia.

Since the study focused on zero equivalence, the entire dictionary was taken as a base for extracting cases of zero equivalence. Zero equivalence is marked in two ways: with a slashed zero (Ø), which indicates a complete absence of a dictionary equivalent in the TL; and with a hash sign (\#), which indicates the absence of equivalence at word level but not at the level of the entire message.

The material collected was first analysed as to the part of speech of the lemmata to see whether any part of speech stands out as regards zero equivalence. Each lemma or sense of the lemma with zero equivalence was then 
investigated more thoroughly, with the aim of identifying any potential features that may be considered a reason for zero equivalence and possible solutions offered by the lexicographers. Special attention was also paid to examples of use and their translations into the TL. Moreover, a content analysis of examples of use was made to see whether these examples share any features that could potentially be regarded as a reason for zero equivalence.

\section{Results}

The analysis of the material gathered showed that 65 lemmata in the ESD contain a slashed zero, a hash or both. The total number of hash signs used in the ESD is 92, but closer observation shows that one and the same entry can contain more than one hash, which means that the total number of lemmata with a hash sign is lower, since hash signs are found in 41 lemmata. The same holds true for the slashed zero, which can be found in 29 lemmata, but one lemma can contain one or more senses marked with a slashed zero, thus the total number of slashed zeros is 40. Interestingly, five lemmata (of, out,'s, the and up) contain senses marked with both signs.

\begin{tabular}{|c|c|c|}
\hline Part of speech & No. of lemmata with \# & No. of lemmata with $\varnothing$ \\
\hline Verb & 12 & 9 \\
\hline Noun & 11 & 3 \\
\hline Adjective & 7 & 0 \\
\hline Preposition & 5 & 2 \\
\hline Adverb & 2 & 7 \\
\hline Pronoun & 1 & 4 \\
\hline Article & 0 & 3 \\
\hline Others & 3 & 1 \\
\hline TOTAL & 41 & 29 \\
\hline
\end{tabular}

Table 1: Lemmata with hash signs and slashed zeros by parts of speech

A hash sign can be found to mark the absence of equivalence in one or exceptionally several senses of the lemma, phraseological unit or - in verbal lemmata - multi-word verb. A slashed zero marks zero equivalence in one or several senses of the lemma only and cannot be found in idioms and phrasal verbs sections. More detailed results will be presented below by parts of speech of the lemmata. 


\subsection{Verbs}

The majority of verbal entries contain a hash sign to indicate lack of dictionary equivalent in one sense of the lemma (9 verbs: bear, begin, bless, bother, bugger, commit, get, let, may). In the entry for the verb come, three senses (i.e., 8, 9 and 12) are marked by the use of a hash, but senses 8 and 9 additionally include an explanatory phrase or a pattern illustration:

- sense 8: the explanatory phrase $v$ vprašalnih stavkih za how 'in questions after how' precedes the hash (e.g., How do you come to be so late? Kako to, da si tako pozen?);

- sense 9: come sth (with sb) before the hash signifies a pattern (e.g., Don't come the innocent with me! Ne delaj se nedolžnega!);

- sense 12: translated examples are included following two patterns, i.e., come + gerund (e.g., come flying prileteti; come sobbing prihlipati) or come + prepositional phrase (e.g., come into effect stopiti v veljavo, začeti veljati; come into force stopiti v veljavo, začeti veljati).

In the verbal lemmata cry and go, a hash is used in the idioms section to mark the absence of a dictionary equivalent for a phraseological unit. The verb cry is used in the phraseological unit cry over spilt (AmE spilled) milk, whose meaning is illustrated by a translated example (It's no use crying over spilt milk. Po toči zvoniti je prepozno.). The verb go is used in the phraseological unit be going to do sth, defined as 'used to show what somebody intends to do in the future' and 'used to show that something is likely to happen very soon or in the future'. In the ESD, both senses in English are translated into Slovene grammatically by the future tense form (e.g., She's going to ring us. Poklicala nas bo.). Apart from that, the phraseological unit is accompanied by the explanatory phrase za izražanje prihodnosti 'used to express future'.

The analysis of verbal entries containing a slashed zero shows that our material contains three auxiliary verbs, five modal verbs, one full lexical verb and the informal contraction of does i.e., 's. The auxiliary verbs be, do and have do not have an equivalent in Slovene when they act as operators, i.e., the first verb in a finite verb phrase (cf. Quirk et al. 1985: 120) (e.g., What does he want? Kaj želi?).

As opposed to auxiliary verbs, which share an association with the basic grammatical categories of tense, aspect and voice, the modal verbs mainly express modal meanings, such as possibility, obligation and volition (Quirk et al. 1985: 129). In the ESD, five out of nine verbs with at least one sense where zero equivalence can be observed belong to modal verbs, i.e., can, should, used to, will and would. Only one sense of the modal verb can is characterized by zero equivalence, i.e., the use of can with verbs of perception and with mental-state verbs: e.g., I can't hear you. Ne slišim te. As can be seen from this example, the Slovene translation contains only the full verb (i.e., hear = slišati), whereas the modal verb can remains untranslated. In the entry for the modal verb should, 
only one sense cannot be rendered into Slovene. The examples of use included for this particular sense show that the lexicographers gathered examples illustrating the use of different senses of the verb should that have no equivalent in Slovene and translated them under this specific sense. In the modal verbs will and would, only one sense that they both have in common is characterized by zero equivalence, i.e., descriptions of personal habits or characteristic behaviour. As is evident from examples illustrating the use of will and would in this sense, only the full verbs are translated into Slovene, whereas the modal verbs are left out in the Slovene translations (e.g., She will spend hours on the telephone. Cele ure preživi na telefonu.; Her grandparents would take care of her. Zanjo so skrbeli stari starši.). The modal verb used to expresses habitual and state meanings. Slovene, however, does not make use of a modal verb in this function, which means that used to is not rendered into Slovene by a corresponding modal verb (e.g., Did he use to work here? Ali je delal tukaj?). The translated examples show that Slovene translations contain the imperfective form of the full verb in the past tense, but no modal verb is used in the translation.

Have is the only full lexical verb in our database with one out of fourteen senses characterized by zero equivalence. This is the causative use meaning 'to cause something to be done for you by somebody else' (e.g., He had his head cut off. Obglavili so ga.). The translation into Slovene contains the translation of the full lexical verbs in the English example (e.g., cut off = obglaviti); these verbs are (usually) in the third person plural, which here suggests generic or impersonal use.

Apart from the symbol $\varnothing$, some senses of the auxiliary verbs as well as of modal verbs are also equipped with short descriptions of the function of the auxiliary verb. For instance, (the verb be) s sedanjim deležnikom za tvorbo nedovršnih časov 'with the present participle to form progressive tenses'; (the verb can) z glagoli, ki izražajo čute in mišljenje 'with verbs expressing perception and the mind'.

\subsection{Nouns}

In nominal lemmata, a hash can be found to indicate the absence of dictionary equivalents for one of the senses of the lemma (in eight lemmata) or in the idioms section to denote lack of equivalence for a phraseological unit (in three phraseological units). Lack of dictionary equivalents at sense level is especially interesting in the noun brainchild. Brainchild is a monosemous noun, which means that a dictionary user is offered no equivalents in the TL and can infer the meaning of the lemma from one translated example only (The system was his own brainchild. On je bil duhovni oče tega sistema.).

In the entries for the nouns accident, amount and comfort, the hashes appear in the idioms sections to mark a lack of dictionary equivalents for phraseological units: 
- an accident of birth: By accident of birth he is entitled to American citizenship. Ker se je slučajno rodil v Ameriki, ima pravico do ameriškega državljanstva.

- too close/near for comfort: The bombs fell in the sea, many too close for comfort. Bombe so padale v morje, mnoge veliko preblizu. The translation into Slovene depends on the English adverb (close, near) used in the phraseological unit (too close/near $=$ preblizu) .

- no amount of sth will do sth: No amount of persuasion could make her change her mind. Naj so jo še tako prepričevali, mnenja ni spremenila. The pragmatic meaning 'used for saying that something will have no effect' is clearly expressed in the Slovene translation.

Pragmatic meaning can also be observed in the entry for the noun goodness defined as 'used to express surprise'. In this sense, the noun lacks dictionary equivalents in Slovene, but the illustrative examples show that the noun is used in more or less fixed expressions, although the lexicographers obviously did not decide to include them in the idioms section. Nevertheless, the translation into Slovene clearly reflects the pragmatic meaning of the English noun ( $M y$ goodness! or Goodness me! or Goodness gracious (me)! Moj bog!).

Zero equivalence marked with a slashed zero can be found in three nominal lemmata (piece, round, space) in the ESD. In the sense 'a single item', piece is used in a construction consisting of a partitive (i.e., piece) linked by the preposition of to another noun (e.g., research, advice) and expressing quantity partition. The noun piece is not translated into Slovene, since its only function is to express the quantity and thus countability of English uncountable nouns. The nouns raziskava 'research' and nasvet 'advice' are countable in Slovene, as opposed to English where they are uncountable; therefore, no additional lexical item is needed in Slovene to express plurality. A partitive use can also be observed in one sense of the noun round, which remains untranslated in Slovene. In the partitive sense, round is used with applause and cheers to mean 'a short period during which people show their approval of somebody/something by clapping, etc.'. The only way of showing the users that round in this sense does not have an equivalent in Slovene is to include translated examples (i.e., round of applause aplavz, ploskanje; round of cheers vzklikanje, pozdravljanje).

\subsection{Adjectives}

The dictionary under investigation includes seven adjectival lemmata with a hash sign. The hash is used to mark the absence of dictionary equivalents for one phraseological unit, i.e., wouldn't be seen/caught dead in/at/with sth and its variant form wouldn't be seen/caught dead doing sth, which is included in the idioms section of the lemma dead. In all other cases, the hash is used to indicate lack of equivalence for one specific sense of the lemma and is followed by translated illustrative examples. The adjective delayed-action is monosemous, which means that the hash sign indicates a complete lack of dictionary equivalents 
and two examples following the same pattern, i.e., delayed-action + noun, are provided for the dictionary user to retrieve necessary semantic information. Both examples could be regarded as compounds, or more precisely, as terms, and are also rendered into Slovene as such: delayed-action bomb bomba s tempirnim vžigalnikom and delayed-action mechanism samosprožilec.

Three adjectival lemmata marked with a hash in the ESD, i.e., gracious, great and holy, have some characteristics in common. Firstly, the sense with no dictionary equivalents in Slovene has a pragmatic definition in English: gracious 'used for expressing surprise'; great 'used to express shock or surprise'; holy 'used to emphasize that you are surprised, afraid, etc.'. Secondly, they all express restrictions and constraints regarding usage, which are reflected in the accompanying labels: gracious labelled becoming old-fashioned; great labelled spoken old-fashioned; holy labelled informal. Thirdly, the examples illustrating the use of the lemma with no equivalents are fixed expressions rather than free combinations:

- gracious: Good(ness) gracious! or Gracious me! Moj bog! (two variant forms of the same expression rendered into Slovene in exactly the same way)

- great: Great heavens! Za božjo voljo.

- holy: Holy cow/cats/mackerel/shit/smoke! Za božjo voljo!, Sveta nebesa!

\subsection{Prepositions}

The senses of the prepositional lemmata marked by a hash sign are mostly characterized by a higher number of examples if compared with the number of examples illustrating the senses of lemmata with zero equivalence belonging to other parts of speech. In all prepositional lemmata, the hash is used to mark the absence of equivalents in one sense only rather than to indicate an absence of equivalents in the idioms section.

A careful analysis of prepositional lemmata shows that the sense marked by a hash sign in the ESD contains examples illustrating different senses of the lemma in English. The absence of dictionary equivalents is a characteristic shared by these English senses. This can best be exemplified with the entry for $b y$, in which the following four senses in English are represented as one sense in the ESD:

- 'used to say that something happens in a particular kind of light': e.g., by day podnevi; by moonlight $\mathrm{v}$ mesečini; by daylight pri dnevni svetlobi;

- 'used to state the rate at which something happens': e.g., day by day iz dneva $\mathrm{v}$ dan; bit by bit pomalem;

- 'used before particular nouns without the, to say that something happens as a result of something': e.g., by mistake pomotoma; by accident po nesreči;

- 'used to show how something is done': e.g., by yourself sam.

In the ESD, two prepositions marked with a slashed zero in at least one sense 
are included, i.e., at and of. According to Quirk et al. (1985: 665), at can be used to indicate space, time, goal, target, stimulus, standard and reaction, whereas of indicates cause, means, subject matter and material. These various senses are also reflected in translations, but there are contexts in which the two prepositions lack an equivalent in Slovene. This can best be seen if we study the examples in the ESD that illustrate the use of at (e.g., at large na prostosti; at least vsaj; be at its best biti najlepši). Similarly, the examples of use found in the entry for the preposition of exhibit the same characteristic (e.g., a friend of mine moj prijatelj; some of my friends nekateri moji prijatelji; a girl of ten desetletna deklica; the role of the teacher učiteljeva vloga). Of is frequently used as a postmodifier in noun phrases in a function similar to that of the genitive, which also corresponds to some of the examples of use. In this function, the noun in the genitive is often used in the Slovene translation, but this is not the only possibility for translating of followed by a noun phrase. As can be seen from the above examples, the following two options exist: translation by means of an adjective (e.g., the role of the teacher učiteljeva vloga - učiteljev is an adjective); translation by means of a determinative possessive (e.g., a friend of mine moj prijatelj - moj is a possessive pronoun).

\subsection{Adverbs}

Two adverbial lemmata in the ESD are marked by the use of a hash sign, i.e., jolly and out. In the entry for jolly, the hash appears in the idioms section to mark the absence of dictionary equivalents for the phraseological unit jolly well, which is defined by the pragmatic definition 'used to emphasize a statement when you are annoyed about something'. Its connotative value is marked by the labels informal, old-fashioned, British English. This phraseological unit is illustrated by translated examples (e.g., I'm going to jolly well tell him what I think of him! Mu bom že povedal, kaj si mislim o njem.). In the ESD, one out of twenty-four senses of the adverb out is characterized by the absence of dictionary equivalents. This sense corresponds to the following senses in English: 'used to show that something/somebody is removed from a place, job, etc.' and 'used to show that somebody is no longer involved in something'.

When studying the senses of the adverbs along, away, out, there, through, up and very with the slashed zero, it becomes obvious that the adverb is sometimes part of a multi-word verb. For example, in the ESD, the senses of along and away, which cannot be translated into Slovene without the accompanying verb, are illustrated by examples such as: How are things coming along at work? Kako gre delo?; The water boiled away. Voda je povrela. As to the first example, along is part of the multi-word verb come along meaning 'to improve or develop in the way that you want'. Similarly, boil away used in the second example is also a multi-word verb meaning 'if a liquid boils away, or if you boil it away, it disappears and turns to gas after reaching a very high temperature'. The spatial senses of out ('a long or a particular distance away from a place or from land'), 
up ('to or at an important place, especially a large city') and through ('travelling through a place without stopping or without people having to get off one train and onto another') represented in the examples in the ESD remain untranslated in Slovene (e.g., live out in the country živeti na deželi; be up at Oxford biti na oxfordski univerzi; go straight through to iti naravnost v). Existential there is also marked with the symbol $\varnothing$ indicating zero equivalence and its function can only be made clear to the users of a bilingual English-Slovene dictionary by including examples translated into Slovene (e.g., There's a cinema around the corner. Kino je za vogalom.). One sense of the adverb very, i.e., 'used to emphasize a superlative adjective or before $o w n$ ' is characterized by zero equivalence. Very as an intensifier here premodifies the nonperiphrastic superlative or the emphatic determinative own. It is clear from the examples illustrating this meaning of very in the ESD (the very best quality najboljša kakovost; the very last time zadnjič; her very own car čisto njen avtomobil) that the Slovene translation may also contain the superlative, although the superlative in Slovene is not premodified by any word, e.g., the superlative of the adjective dober 'good', i.e., najboljši 'the best'. The adverb zadnjič is an equivalent of the last time, whereas čisto njen avtomobil is translated literally as 'an entirely her car', which means that an intensifier is also used in Slovene as a premodifier of the possessive pronoun njen 'her'.

\subsection{Pronouns}

The only pronominal lemma with a hash sign is one. The hash is used to indicate the absence of equivalents for one out of six senses, i.e., 'used to avoid repeating a noun, when you are referring to somebody/something that has already been mentioned, or that the person you are speaking to knows about'.

Four pronominal lemmata included in the ESD are marked with a slashed zero. If we analyse these lemmata more carefully, we can see that the indefinite pronoun any is not rendered into Slovene in contexts such as We got home without any difficulty. Domov smo prišli brez težav.; I haven't any idea. Pojma nimam and the personal pronoun it in contexts such as Stop it! Nehaj! (the Slovene translation contains the imperative of the verb nehati 'stop'); What about/of it? Zakaj sprašuješ? (the Slovene translation can be glossed as 'Why are you asking?'). In these contexts, it is used anaphorically, its meaning being 'used to refer to a fact or situation that is already known or happening'. In the entries for the demonstrative pronouns this and these one sense characterized by zero equivalence can be found in the ESD. Contexts illustrating the absence of a dictionary equivalent are as follows: This is Mary speaking. Mary tukaj.; these trousers of mine moje hlače. In the latter example, the demonstrative pronoun functions as a premodifier in a nominal phrase which is postmodified by of + independent possessive. In the Slovene translation, the demonstrative pronoun is dropped and the whole structure is translated by means of the possessive pronoun followed by the noun (moje hlače 'my trousers'). It should be pointed out 
that Slovene does not distinguish between determinative and independent possessives and therefore, the translation of such examples corresponds to the translation of the combination determinative possessive + noun, which is also the reason for zero equivalence in this sense of this/these in the ESD.

\subsection{Miscellaneous}

In the ESD, three lemmata with a hash sign lack the part-of-speech label (see Table 1 under Others), i.e., the lemmata d'you, gonna and let's. All three lemmata are monosemous and represent short or informal forms. The example with d'you is translated as a question in the present and past tense forms (What'd you say? Kaj praviš?, Kaj si rekel?), gonna is translated using the future tense form in Slovene (This isn't gonna be difficult. To ne bo težko.) and let's is translated using the imperative form of the verb in the first person plural (Let's go to the cinema. Pojdimo v kino.). It could be said that all three lemmata are translated grammatically rather than lexically. Apart from that, the use of gonna is additionally described by a short explanatory phrase, i.e., pogovorna oblika za going to, ki izraža prihodnost 'an informal form for going to used in reference to the future'.

Three dictionary entries with a slashed zero treating either the definite (the, ye) or indefinite article (a) can be found in the ESD. The English articles can sometimes be rendered into Slovene, but in certain contexts, they cannot possibly be translated. This is illustrated by some typical contexts in the dictionary under investigation: Do you have a car? Ali imate avto?; the house at the end of the street hiša na koncu ulice; Ye Olde Bull Stari bik. The Slovene nouns avto 'car', hiša 'house' and bik 'bull' are not premodified by any determiner, and the kind of reference a particular noun phrase has in English is lost in the Slovene translation. It is, therefore, impossible to say on the basis of the Slovene translations whether a certain noun phrase has indefinite reference (indicated by the indefinite article) or definite reference (indicated by the definite article).

\section{Discussion}

The absence of dictionary equivalents is an issue which should be adequately addressed by bilingual lexicographers, who should base their decisions and solutions on an in-depth lexical and grammatical contrastive analysis. This analysis can give them clear insight into the differences of the lexical meaning of the two lexical units as well as the grammatical functions in the respective languages. Special attention should be paid to the various co-texts and contexts in which the lexical item in question is used in the TL and to its rendering into the SL. If different co-texts and contexts suggest that the provision of a dictionary equivalent is not possible, this does not necessarily mean that the lexical item in the SL is untranslatable or untranslated, let alone omitted in the TL. Just 
the opposite, an SL lexical item does not disappear in the TL context; however, its equivalence can only be observed at the level of the entire message rather than at word level. In many cases, the lexicographers are faced with the problem of a complete absence of equivalence when dealing with grammatical words. We cannot but agree with Zgusta (1971: 115), who claims that grammatical words are just a part of the total lexicon of the language and lexicographers have to register them and to indicate their meaning, or more precisely, to indicate when and how they are used and with what grammatical function. These words are language-specific, which means that many of their functions in one language are carried out in another language in a completely different way, and no parallels can be drawn between the languages. The semantic content of grammatical words may not even be mentioned in a bilingual dictionary; instead, lexicographers include a description of the function of the lemma in a particular sense, which is also the case in the ESD. Or, as stated by Atkins and Rundell (2008: 472-473), grammatical information is provided instead of lexical equivalence. If no equivalent can be included, the lexicographers need to employ other means to show how the lemma or one of its senses can be translated in specific types of contexts, which means that they should include translated examples of use (for more comprehensive treatment of examples of use in a bilingual dictionary, see Vrbinc and Vrbinc 2016).

In what follows, entries containing senses with zero equivalents are discussed from the pragmatic, lexico-grammatical, lexical and grammatical points of view and possible solutions are proposed.

\subsection{Zero equivalence in pragmatic senses}

The results show that there is a notable lack of dictionary equivalence in those senses of the lemmata that express pragmatic meaning in the SL. Lexicographers are often faced with lexical items that encode not only a meaning but also an attitude, emotion or a certain degree of politeness and formality conventions, which can reinforce or contradict the speaker's intended meaning (Hartmann and James 1998: 111). This means that a word or word combination can express not only meaning but also the feeling and opinions of the speakers. This is in line with the findings of our study, since we also observed that in a high number of senses reflecting pragmatic use, the reference is to feelings, emotions and opinions. As Atkins and Rundell (2008: 422) state, corpus data show that the speaker's attitude tends to be conventionally lexicalized only in a fairly limited number of frequently occurring words and phrases. Consequently, the lexicographic treatment of lexical items with pragmatic characteristics differs from the treatment of other lexical items. In some cases, dictionary equivalents can be provided which are immediately insertable into the context, but in many cases, contrastive differences between the SL and TL cause untranslatability at word level; therefore, lexicographers are forced to use cotext or context to show how an SL lexical item is reflected in the TL, which is 
also the case in the ESD.

In the entries for gracious, great, holy, goodness and bless, the hash is used to indicate the absence of equivalence of a pragmatic sense at word level. Taking a closer look at the examples illustrating these senses, we can see that all of them are idiomatic to a certain extent, which is also reflected in their idiomatic translations into Slovene. Given their idiomatic characteristics, they could also be included in the idioms section of the respective entries. If that were the case, zero equivalence would not be an issue, since the sentential form has a perfect equivalent in the TL, i.e., in Slovene.

\subsection{Zero equivalence due to lexico-grammatical differences between SL and TL}

The contrastive analysis of the examples illustrating the semantics of the senses marked by the hash sign clearly shows that it is not uncommon to find examples combining lexical and grammatical characteristics. This can be attributed to the distinct structure of languages resulting in the fact that they express different characteristics in different ways. Good examples are the English verbs come used in the patterns come + gerund and come + prepositional phrase and get used in the patterns get something done and get + adjective, which are translated into Slovene using the perfective form of the verbs. Similarly, some senses of modal verbs also express grammatical as well as semantic features. A repetitive action in the past (would and used to), for instance, has no direct equivalent in Slovene; therefore, the only option left to a lexicographer is to resort to examples of use. By translating English examples, the lexicographer gives the appropriate information needed by a dictionary user without having to provide lengthy and complicated theoretical explanations of a specific function.

The use of the article poses problems for the target users of the ESD, i.e., native speakers of Slovene, because articles are not used in Slovene at all and consequently, no parallels can be drawn between English and Slovene as regards articles. In most cases, the English articles are simply dropped in rendering a translation in Slovene. Apart from that, the use of articles in English is often idiomatic and therefore highly unpredictable for non-native speakers. Therefore, the dictionary users should be made aware of the absence of an equivalent in specific contexts by the symbol $\varnothing$ and translated examples.

\subsection{Zero equivalence due to grammatical differences between SL and TL}

The primary function of the auxiliary verbs $b e$, do and have is to express grammatical relations. They may have different functions in the verb phrase, but their ability to act as operators should be emphasized, since this function is the most common cause of problems for lexicographers when they try to provide dictionary equivalents in a bilingual dictionary. If we take a look at the tense formation in both languages of the ESD, we can see that tenses in Slovene are 
formed in a way completely different from how tenses are formed in English. The primary reason for that is that these two languages belong to different types of languages according to morphological linguistic typology: English is an analytic language, while Slovene is a synthetic language. This means that English conveys grammatical relations without using inflections; Slovene, on the other hand, makes abundant use of inflections and exhibits a high morphemeper-word ratio. In Slovene, the same content may be expressed by using completely different structures or specific lexical items.

From the perspective of a non-native speaker, the phraseological unit be going to do sth deserves special attention. In the ESD as well as in monolingual learner's dictionaries, it can be found in the idioms section, but a non-native speaker of English is unlikely to search the idioms section for this word combination. In the process of learning English as a foreign language, learners are taught that this structure is used to form the future tense which expresses intentions, plans, etc. in the future. Therefore, it would be advisable to avoid including this structure in the idioms section of a mono- or bilingual dictionary as a phraseological unit, but rather to treat it as a separate sense with a fixed pattern and a brief theoretical explanation followed by illustrative examples, which should be translated in a bilingual dictionary. The same solution can be provided in other cases where grammatical differences between the SL and the TL exist. For instance, in nominal lemmata, one case of zero equivalence described in the Results section concerns the partitive constructions used to make English uncountable nouns countable. A contrastive analysis shows that in Slovene, the nouns used as equivalents of English uncountable nouns included in our study are countable.

A theoretical explanation providing grammatical information instead of lexical equivalence is sometimes included to help the user to more fully understand the use of the lemma in question (e.g., be going to do sth, come, gonna, be, have, can). It must be stressed that the ESD includes explanations that are short, precise, to the point, and above all, characterized by the use of very simple language with almost no technical terms. The metalanguage used in the ESD is Slovene, which also holds true for the short descriptions, since the dictionary is primarily intended for native speakers of Slovene. The native language of the primary target users seems to be the only sensible choice for the metalanguage (cf. Atkins and Rundell 2008: 234), especially if the dictionary is pedagogically oriented, which is the case with the ESD. Short descriptions can be regarded as valuable, since they represent a short comment on the specific use dealt with in a specific sense. In the ESD, they are provided in brackets, are typographically distinct from dictionary equivalents and precede the hash or slashed zero.

\subsection{Zero equivalence due to lexical differences between SL and TL}

The issue of zero equivalence in adverbial lemmata is often connected with the use of adverbs in multi-word verbs. It should be stressed that in lexicography, 
no distinction is made between phrasal verbs, prepositional verbs or phrasalprepositional verbs. In practice, all multi-word verbs are included and treated under verbal lemmata in a special section (the phrasal verbs section), but in adverbial lemmata we can also come across examples of multi-word verbs. The reason is that lexicographers try to define (in monolingual dictionaries) or translate (in bilingual dictionaries) the meaning of a particle that is a constituent element of a multi-word verb, since the combination of a full lexical verb and a particle or two particles poses problems for non-native speakers of English, who need to learn the meaning of the whole combination. It should be pointed out that multi-word verbs are a peculiarity of English with no exact parallel in Slovene, which means they deserve careful and appropriate treatment. If multi-word verbs were not included in the ESD under adverbial lemmata, the problem of zero equivalence would be resolved, since the comprehension of the adverb does not contribute to the comprehension of the multiword verb. It is therefore advisable to include multi-word verbs under verbal lemmata only and to avoid listing them under adverbial lemmata.

As far as pronominal lemmata with zero equivalence are concerned, the pronoun any used as a non-assertive pronoun in negative sentences lacks an appropriate equivalent in Slovene. Thus, the treatment as provided by the ESD can be assessed as appropriate, since zero equivalence is presented in the form of translated examples of use. The same observation can be made in connection with the personal pronoun it, which according to Quirk et al. (1985: 348-349) is the most neutral and semantically unmarked of the personal pronouns, and this is also reflected in Slovene translations of the examples in the ESD.

If we take a close look at the prepositional lemmata, we can see that in the entry for at, the examples included in the ESD are idiomatic expressions which should be learnt as whole chunks of lexical semantic-syntagmatic entities (Alexander 1989: 16), since they are semantically mostly not reducible to their immediate constituents. Consequently, at is not translated into Slovene, and its absence in the Slovene translation is indicated to make the user aware of zero equivalence. Here, a parallel can be drawn between these idiomatic expressions and multi-word verbs in that it is much more appropriate to include idiomatic expressions under the first full lexical word in the expression rather than under the preposition.

\subsection{Other cases of zero equivalence}

Our research clearly shows that, in many cases, several senses of a lemma in the SL are characterized by a lack of dictionary equivalence in the TL. As stated by Zgusta (1971: 315), a monolingual dictionary of the SL can be regarded only as a first orientation when gathering information about the meaning of an SL lexical item, but the comparison of the SL and TL lexical items should be made by the contextual method to identify the potential differences between languages. As a rule, the lexicographers compiling the ESD decided to include all 
senses of the lemma in English with zero equivalence in Slovene under one sense, the only exception to this rule being the lemma come, where three senses have a hash sign. The reason for this exception is that two senses are characterized by a specific structure (i.e., sense 8 , 'in questions after how'; sense 9 , come sth (with sb)). The reduction in the number of senses with a hash seems a sensible decision and can be regarded as a way of simplifying the dictionary entry structure, which is a welcome feature in complex polysemous entries where dictionary users struggle to find the right sense.

\section{Conclusion}

In bilingual dictionaries, contrastive differences between the SL and TL, as well as features typical of either the SL or the TL, result in different types of equivalence, which are treated by lexicographers in a wide variety of ways. The focus of our study is on how bilingual lexicographers tackle the problem of zero equivalence, since they should not refrain from attempting to fill lexical gaps existing between the SL and the TL. One of the most important conclusions is that, if equivalence cannot be achieved by providing a dictionary equivalent, the problem can be resolved by including examples of use which should be selected very carefully by the lexicographers to enable the users to become familiar with different contexts in which the lemma or one of its senses is used. The most important function of examples in a bilingual dictionary is to show contrastive differences between two languages and to illustrate the differences between the dictionary equivalent(s) offered in the dictionary and the translation of the lemma in context. It should, however, be stressed that it is absolutely necessary to provide a translation of illustrative examples into the TL (Vrbinc and Vrbinc 2016: 308). If the examples remain untranslated, the user is not made aware of the problem of non-equivalence; it could therefore be claimed that such a bilingual dictionary does not fulfil one of its main tasks, i.e., to clearly show how two different languages function in everyday use. We cannot but agree with Gouws (2002: 208), who points out that "[c]otext and context can play an important role to ensure an optimal retrieval of information from bilingual dictionaries", since lexical items always occur with their collocates; consequently, one can expect them to appear in a similar co-text or context, thus influencing the way they are used in speech and writing. To compensate for the absence of dictionary equivalents, the lexicographers in the ESD resorted to translated examples of use, which can be considered appropriate if the dictionary is to function as an effective communication tool.

To conclude, the main objective of the compilers of any bilingual dictionary is to offer the users dictionary equivalents that can fit as many contexts as possible and can be immediately insertable when translating from the SL into the TL. In cases where no equivalents exist, the users should be offered workable solutions which enable them to deal successfully with the absence of dictionary equivalents. The approaches and solutions used by the lexicographers 
compiling the ESD can help dictionary users to make more effective use of the dictionary even in cases where no parallels can be drawn between their mother tongue and a foreign language, thus achieving a more successful and thorough retrieval of information with every look-up.

\section{References}

Adamska-Sałaciak, Arleta. 2010. Examining Equivalence. International Journal of Lexicography 23(4): 387-409.

Adamska-Sałaciak, Arleta. 2011. Between designer drugs and afterburners: A Lexicographic-Semantic Study of Equivalence. Lexikos 21: 1-22.

Alexander, Richard John. 1989. Fixed Expressions, Idioms and Collocations Revisited. Meara, Paul (Ed.). 1989. Beyond Words: 15-24. London: Centre for Information on Language Teaching and Research/British Association for Applied Linguistics.

Atkins, Beryl T. Sue. 1992/1993. Theoretical Lexicography and its Relation to Dictionary-Making. Dictionaries 14: 4-43.

Atkins, Beryl T. Sue and Michael Rundell. 2008. The Oxford Guide to Practical Lexicography. Oxford/ New York: Oxford University Press.

Gouws, Rufus H. 2002. Equivalent Relations, Context and Cotext in Bilingual Dictionaries. Hermes, Journal of Linguistics 28: 195-209.

Hartmann, Reinhard Rudolf Karl and Gregory James. 1998. Dictionary of Lexicography. London/ New York: Routledge.

Hu, Shuqin. 2010. Context of Situation in Translation. Journal of Language Teaching and Research 1(3): 324-326.

Quirk, Randolph, Sidney Greenbaum, Geoffrey Leech and Jan Svartvik. 1985. A Comprehensive Grammar of the English Language. London/New York: Longman.

Svensén, Bo. 2009. A Handbook of Lexicography: The Theory and Practice of Dictionary-Making. Cambridge: Cambridge University Press.

Šipka, Danko. 2015. Lexical Conflict: Theory and Practice. Cambridge: Cambridge University Press.

Vrbinc, Alenka and Marjeta Vrbinc. 2016. Illustrative Examples in a Bilingual Decoding Dictionary: An (Un)necessary Component? Lexikos 26: 296-310.

Wiegand, Herbert Ernst. 2002. Equivalence in Bilingual Lexicography: Criticism and Suggestions. Lexikos 12: 239-255.

Wiegand, Herbert Ernst. 2005. Äquivalenz, Äquivalentdifferenzierung und Äquivalentpräsentation in zweisprachigen Wörterbüchern: Eine neue einheitliche Konzeption. Gottlieb, Henrik, Jens Erik Mogensen and Arne Zettersten (Eds.). 2005. Symposium on Lexicography XI. Proceedings of the Eleventh International Symposium on Lexicography May 2-4, 2002 at the University of Copenhagen: 17-57. Tübingen: Max Niemeyer.

Zgusta, Ladislav. 1971. Manual of Lexicography. Prague: Academia / The Hague/Paris: Mouton. 